Annals of Plant and Soil Research 22(4): 415-419 (2020)

https://doi.org/10.47815/apsr.2020.10014

\title{
Effect of nitrogen and topping on performance of bidi tobacco (Nicotiana tabacum L.) varieties under rainfed conditions
}

\section{S. JAFFAR BASHA ${ }^{*}$, P. PULLI BAI, S. KASTURI KRISHNA ${ }^{1}$ AND C. CHANDRASEKHARA RAO ${ }^{1}$}

Regional Agricultural Research Station, Acharya N.G.Ranga Agricultural University

Nandyal-51850, Kurnool District, Andhra Pradesh, India

Receive:d: June, 2020; Revised accepted: August, 2020

\begin{abstract}
A field experiment was undertaken at Regional Agriculture Research Station, Nandyal, Andhra Pradesh for two consecutive years viz., 2018-19 and 2019-20 on Vertisols under rainfed condition to study the effect of different levels of nitrogen and topping on performance of bidi tobacco (Nicotiana tabacum L.) varieties. The treatments consisted of two varieties as main plots, three nitrogen levels as sub plots and three topping levels as sub sub plots in split split plot design and replicated thrice. The data pooled over two seasons revealed that significantly higher leaf length (47.6 $\mathrm{cm})$, leaf width $(21.3 \mathrm{~cm})$ and cured leaf yield $\left(2217 \mathrm{~kg} \mathrm{ha}^{-1}\right)$ were recorded with variety ABD 132 over other variety Nandyal Pogaku 1. Application of $140 \mathrm{~kg} \mathrm{~N}^{-1}$ recorded higher leaf length $(47.7 \mathrm{~cm})$, leaf width $(20.9 \mathrm{~cm})$ and cured leaf yield $\left(2110 \mathrm{~kg} \mathrm{ha}^{-1}\right)$. The topping at 15 leaf stage recoded higher cured leaf yield $\left(2147 \mathrm{~kg} \mathrm{ha}^{-1}\right)$ over other topping stages. Higher net returns (Rs $\left.105544 \mathrm{ha}^{-1}\right)$ with BCR of 2.72 were recorded with ABD 132 over Nandyal Pogaku 1. Application of $110 \mathrm{~kg} \mathrm{~N}^{-1}$ recorded higher BCR of 2.55 whereas topping at 15 leaf stage recorded higher net returns (Rs 100275 ha $^{-1}$ ) with BCR of 2.64. ABD 132 recorded higher nicotine (5.94\%), lower reducing sugars $(2.25 \%)$ and higher chlorides $(1.61 \%)$ when compared to Nandyal Pogaku $1(5.71 \%, 2.97 \%$ and $1.23 \%$ respectively). The levels of nitrogen and topping had non-significant effect on leaf chemical constituents. The interactive effect among various treatments had significantly beneficial effect on cured leaf yield of bidi tobacco and maximum cured leaf yield was obtained with ABD 132 with $140 \mathrm{~kg}$ $\mathrm{N}$ ha ${ }^{-1}$ and topping at 15 leaf stage.
\end{abstract}

Keywords: Nitrogen, topping, cured leaf yield, economics, leaf quality

\section{INTRODUCTION}

In Andhra Pradesh, bidi tobacco (Nicotiana tabacum L.) is commercially cultivated under rainfed Vertisols during late rainy season i.e., September ( $2^{\text {nd }}$ fortnight). Usually, farmers apply recommended fertilizer dose in two splits i.e. one as basal and one as top dressing at 30 days after transplanting (DAT). Among the major production factors, optimum nutrition especially nitrogen and level of topping play an important role for maximizing the productivity as well as the quality. Nitrogen is the element that has the highest effect on the growth and quality of 'fluecured' tobacco (Smith, 2009). Nitrogen determines the performance of leaf blade, the qualities and taste of aroma, and the smoke taste (Marchetti et al., 2006). Excessive or improper applications of $\mathrm{N}$ may affect the yield and quality of 'flue-cured' tobacco. Excess nitrogen produces strong and spicy flavors, which are not associated with high nicotine contents. The application of $\mathrm{N}$ greatly influences the crop growth, gas exchange parameters, specific leaf weight, chlorophyll content which in turn affect yield and quality of tobacco (Anuradha et al., 2010). Topping (removal of the flowering head and young leaves) is an essential cultivating measure for air-cured tobacco, which switches the plant from reproductive to vegetative phase (Gooden et al., 2011). Topping increases the size and weight of leaves, increasing the overall yield per hectare (Reed et al., 2012). Topping stage of tobacco is a key time for development of agricultural measures to promote the quality of leaves. Topping stimulates the production of secondary plant products that accumulate in the leaves. These products give the cured leaf improved quality and smoking characteristics. Topping is a turning point for nicotine formation and accumulation inside tobacco plant (Guo et al., 2011). Topping of tobacco not only increases the yield but also improves the quality of cured leaf (Krishna 
Reddy et al., 2012). The package of production technology for bidi tobacco crop involves growing of improved varieties, key agronomic operations including application of optimum dose of nitrogen and topping at proper leaf stage. Nandyala pogaku-1 was released during 2015 from All India Network Project on Tobacco, Regional Agricultural Research Station, Nandyal for cultivation in Vertisols of Andhra Pradesh under rainfed condition. The variety ABD 132 has recorded more leaf thickness, good puckering, less smoke toxicants, high yielding ability with good leaf quality under varietal improvement breeding trials and was in pipeline for release after agronomic evaluation. Hence, the present study was conducted to study the response of bidi tobacco varieties viz., Nandyal Pogaku 1 and ABD 132 to different levels of nitrogen and topping leaf stage.

\section{MATERIALS AND METHODS}

A field experiment was undertaken at Regional Agriculture Research Station, Nandyal, Andhra Pradesh for two consecutive years viz., 2018-19 and 2019-20 on Vertisols under rainfed condition. The treatments consisted of two varieties (ABD 132 and Nandyal Pogaku-1) as main plots, three nitrogen levels $(80,110$ and 140 $\mathrm{kg} \mathrm{ha}^{-1}$ ) as sub plots and three topping levels $(12,15$ and 18 leaf stage) as sub sub plots in split split plot design and replicated thrice. The soil of experimental site was medium deep black, moderately alkaline $(\mathrm{pH}-8.2)$, non saline (EC- $\left.0.11 \mathrm{ds} \mathrm{m}^{-1}\right)$, low in nitrogen $\left(152.3 \mathrm{~kg} \mathrm{ha}^{-1}\right)$, medium in available $\mathrm{P}_{2} \mathrm{O}_{5}\left(32.5 \mathrm{~kg} \mathrm{ha}^{-1}\right)$ and high in available $\mathrm{K}_{2} \mathrm{O}\left(350.9 \mathrm{~kg} \mathrm{ha}^{-1}\right)$. The seedlings were transplanted at planting geometry of $75 \mathrm{~cm}$ $x 75 \mathrm{~cm}$. The treatments were imposed through ammonium sulphate for nitrogen, single superphosphate for phosphorus and sulphate of potash for potassium. Half of the nitrogen, total phosphorus and total potassium were applied as basal and remaining half was applied as top dressing within 30-40 days after planting. An amount of $217.2 \mathrm{~mm}$ rainfall was received in 20 rainy days with $65.8 \%$ deficit compared to normal during 2018 whereas $856.0 \mathrm{~mm}$ rainfall was received in 39 rain days with $45.1 \%$ excess rainfall during 2019.Crop management practices like land preparation, weed control, intercultivation, need based plant protection, de suckering and sun curing were followed as recommended for local area. The data were recorded for plant height, leaf length, leaf width and cured leaf yield at harvest. The leaf samples were used for estimating chemical quality constituents viz., nicotine, reducing sugars (Harvey et al., 1969) and chlorides (Hanumantha Rao et al., 1980). The data gathered in each observation were statistically evaluated using analysis of variance (ANOVA) technique (Panse and Sukhatme 1985). The critical difference (CD) was computed to assess the significance of treatment means at $5 \%$ level of probability.

\section{RESULTS AND DISCUSSION}

\section{Varieties}

The varieties differed significantly for growth parameters, cured leaf yield, economics and leaf chemical parameters (Table 1). Variety ABD 132 recorded higher leaf length $(47.6 \mathrm{~cm})$, leaf width $(21.3 \mathrm{~cm})$, cured leaf yield $(2217 \mathrm{~kg}$ $\mathrm{ha}^{-1}$ ), net returns (Rs $105544 \mathrm{ha}^{-1}$ ), BCR (2.72) and chlorides $(1.61 \%)$ and lower dry weight per unit area $\left(9.34 \mathrm{mg} \mathrm{cm}^{-2}\right)$ and reducing sugars (2.25\%). Variety Nandyal Pogaku 1 recorded lower leaf length $(43.8 \mathrm{~cm})$, leaf width $(18.8 \mathrm{~cm})$, cured leaf yield $\left(1866 \mathrm{~kg} \mathrm{ha}{ }^{-1}\right)$, Chlorides $(1.23 \%)$ and high reducing sugars $(2.97 \%)$. Similar genetic constitutions of the varieties might have contributed for uniformity in plant height, spangle score and nicotine (Gupta et al., 2014; Damodar Reddy, 2015).

\section{Effect of nitrogen}

Plant height did not differ significantly due to nitrogen levels. Application of $140 \mathrm{~kg} \mathrm{~N}$ $\mathrm{ha}^{-1}$ recorded significantly higher leaf length $(47.7 \mathrm{~cm})$, leaf width $(20.9 \mathrm{~cm})$, cured leaf yield $\left(2110 \mathrm{~kg} \mathrm{ha}^{-1}\right)$, net returns (Rs 95,966 ha ${ }^{-1}$ ) with BCR of 2.53 over $80 \mathrm{~kg} \mathrm{~N}^{-1}$. Both higher levels of $N\left(110\right.$ and $\left.140 \mathrm{~kg} \mathrm{ha}^{-1}\right)$ were statistically at par with respect the cured leaf yield. This was probably owing to greater availability of nitrogen and metabolites for growth and yield of the crop. Kumaresan et al. (2014) reported similar results. Leaf chemical parameters did not differ due to different levels of nitrogen. However, higher nicotine (5.99\%), chlorides $(1.47 \%)$, and lower reducing sugars $(2.56 \%)$ were observed with application of 140 $\mathrm{kg} \mathrm{N}$ ha $^{-1}$.As nitrogen has positive correlation 
Table 1:Effect of different levels of nitrogen and topping on growth, cured leaf yield, economics and leaf chemical parameters of bidi tobacco varieties

\begin{tabular}{|c|c|c|c|c|c|c|c|c|c|c|c|}
\hline Treatments & $\mid \begin{array}{c}\text { Plant } \\
\text { height } \\
(\mathrm{cm})\end{array}$ & $\begin{array}{c}\text { Leaf } \\
\text { length } \\
(\mathrm{cm})\end{array}$ & $\begin{array}{c}\text { Leaf } \\
\text { width } \\
(\mathrm{cm})\end{array}$ & $\begin{array}{c}\text { Spangle } \\
\text { score }\end{array}$ & $\begin{array}{c}\text { Dry wt/ } \\
\text { unit leaf } \\
\text { area } \\
\left(\mathrm{mgcm}^{-2}\right)\end{array}$ & $\begin{array}{c}\text { Cured } \\
\text { leaf } \\
\text { yield } \\
\left(\mathrm{kgha}^{-1}\right)\end{array}$ & \begin{tabular}{|c|} 
Net \\
returns \\
$\left(\mathrm{Rs}^{-1}\right.$ \\
$\left.\mathrm{ha}^{-1}\right)$ \\
\end{tabular} & $\mathrm{BCR}$ & $\begin{array}{c}\text { Nicotine } \\
(\%)\end{array}$ & $\begin{array}{c}\text { Reducing } \\
\text { sugars } \\
(\%)\end{array}$ & $\begin{array}{c}\text { Chlorides } \\
(\%)\end{array}$ \\
\hline \multicolumn{12}{|l|}{ Varieties } \\
\hline ABD-132 & 81.7 & 47.6 & 21.3 & 8.06 & 9.34 & 2217 & 105544 & 2.72 & 5.94 & 2.25 & 1.61 \\
\hline Nandyal Pogaku 1 & 79.8 & 43.8 & 18.8 & 7.91 & 10.06 & 1866 & 79174 & 2.29 & 5.71 & 2.97 & 1.23 \\
\hline S.Em & 2.3 & 0.5 & 0.3 & 0.14 & 0.07 & 40.5 & & & 0.10 & 0.02 & 0.01 \\
\hline $\begin{array}{l}\text { C.D. }(\bar{P}=0.05) \\
\text { Nitrogen }\left(k g \mathrm{ha}^{-1}\right)\end{array}$ & NS & 3.2 & 1.9 & NS & 0.45 & 246 & & & NS & 0.12 & 0.09 \\
\hline 80 & 78.8 & 43.2 & 19.2 & 7.89 & 9.18 & 1945 & 86689 & 2.46 & 5.63 & 2.63 & 1.36 \\
\hline 110 & 81.3 & 46.3 & 20.2 & 7.96 & 9.74 & 2070 & 94473 & 2.55 & 5.86 & 2.64 & 1.42 \\
\hline 140 & 82.3 & 47.7 & 20.9 & 8.11 & 10.25 & 2110 & 95966 & 2.53 & 5.99 & 2.56 & 1.47 \\
\hline S.Em+ & 1.9 & 0.4 & 0.3 & 0.10 & 0.32 & 33.5 & & & 0.14 & 0.06 & 0.06 \\
\hline C.D. $(\bar{P}=0.05)$ & NS & 1.3 & 0.9 & NS & NS & 109 & & & NS & NS & NS \\
\hline \multicolumn{12}{|l|}{ Topping stage } \\
\hline 12 Leaf stage & 69.9 & 47.9 & 21.5 & 7.90 & 10.33 & 1908 & 82360 & 2.34 & 5.78 & 2.70 & 1.38 \\
\hline 15 Leaf stage & 82.4 & 45.8 & 20.0 & 8.0 & 9.73 & 2147 & 100275 & 2.64 & 5.8 & 2.5 & 1.43 \\
\hline 18 Leaf stage & 89.9 & 43.4 & 18.6 & 8.00 & 9.08 & 2069 & 94443 & 2.54 & 5.8 & 2.5 & 1.45 \\
\hline S.Em+ & 1.7 & 0.9 & 0.3 & 0.10 & 0.23 & 49.5 & & & 0.14 & 0.06 & 0.05 \\
\hline C.D. $(\bar{P}=0.05)$ & 4.8 & 2.6 & 0.9 & NS & 0.67 & 145 & & & NS & NS & NS \\
\hline Interactions & NS & NS & NS & NS & NS & NS & & & NS & NS & NS \\
\hline CV (\%) & 11.1 & 9.2 & 9.2 & 8.4 & 12.6 & 11.2 & & & 12.2 & 9.7 & 15.3 \\
\hline
\end{tabular}

with nicotine content, there was an increase in nicotine content at higher levels of nitrogen. Marowa et al. (2015) reported that there is still need to establish the nitrogen and priming levels which may vary with place and variety. None of the chemical constituents were significantly changed due to nitrogen levels (Patel et al., 2011). The increase in yield and yield attributes due to increase in $\mathrm{N}$ level was reported by Basha et al. (2018).

Table 2: Interaction effect of nitrogen levels and topping on cured leaf yield ( $\mathrm{kg} \mathrm{ha}^{-1}$ ) of bidi tobacco varieties (Pooled)

\begin{tabular}{|c|c|c|c|c|c|}
\hline \multirow{2}{*}{ Varieties } & \multirow{2}{*}{$\mathrm{N}$ levels $\left(\mathrm{kg} \mathrm{ha}^{-1}\right)$} & \multicolumn{3}{|c|}{ Topping levels } & \multirow{2}{*}{ Mean } \\
\hline & & $12 \mathrm{~L}$ & $15 \mathrm{~L}$ & $18 \mathrm{~L}$ & \\
\hline \multirow[t]{4}{*}{ ABD 132} & 80 & 1840 & 2190 & 2102 & 2044 \\
\hline & 110 & 2215 & 2329 & 2447 & 2330 \\
\hline & 140 & 2149 & 2414 & 2269 & 2277 \\
\hline & Mean & 2068 & 2311 & 2273 & 2217 \\
\hline \multirow[t]{4}{*}{ Nandyal pogaku 1} & 80 & 1643 & 2068 & 1825 & 1845 \\
\hline & 110 & 1633 & 1865 & 1929 & 1809 \\
\hline & 140 & 1969 & 2018 & 1842 & 1943 \\
\hline & Mean & 1749 & 1983 & 1866 & 1866 \\
\hline \multirow{3}{*}{ Mean of $\mathrm{N}$} & 80 & 1741 & 2129 & 1964 & 1945 \\
\hline & 110 & 1924 & 2097 & 2188 & 2070 \\
\hline & 140 & 2059 & 2216 & 2056 & 2110 \\
\hline Topping & & 1908 & 2147 & 2069 & \\
\hline
\end{tabular}

\section{Effect of topping}

Significantly higher plant height $(89.9 \mathrm{~cm})$ was observed when plants were topped at 18 leaf stage and significantly lower $(69.9 \mathrm{~cm})$ with 12 leaf stage topping. Among three topping stages tested, significantly higher leaf length $(47.9 \mathrm{~cm})$, leaf width $(21.5 \mathrm{~cm})$ and dry weight per unit area $\left(10.33 \mathrm{mg} / \mathrm{cm}^{2}\right)$ were recorded with topping at 12 leaf stage. Significantly higher cured leaf yield $\left(2147 \mathrm{~kg} \mathrm{ha}^{-1}\right)$, net returns (Rs $1,00,275 /$ ha) with BCR of 2.64 were recorded S. 
418 with topping at 15 leaf stage and was at par with topping at 18 leaf stage $\left(2069 \mathrm{~kg} \mathrm{ha}^{-1}\right.$, Rs $94,443 \mathrm{ha}^{-1}$ and 2.54 respectively) owing to better topping at 15 leaf stage as compared to other stages of leaf topping. Kasturi Krishna et al. (2004) reported yield increase with increase in topping level. The influence of topping levels on leaf chemistry was non-significant in all the chemical characters (Sannibabu et al., 2014). Similarly Bglar and Behghan (2014) reported that topping at optimum growth stage enhanced tobacco leaf quality in field. Leaf chemical parameters did not differ due to different levels of topping. However, maximum values of these chemical constituents were recorded with topping at 15 leaf stage.

\section{Interaction effect}

There was no significant difference in cured leaf yield among the interactions except between varieties and nitrogen. ABD 132 recorded higher cured leaf yield (2447 kg ha-1) with application of $110 \mathrm{~kg} \mathrm{~N} \mathrm{ha}^{-1}$ and topped at 18 leaf stage and was at par with application of $140 \mathrm{~kg} \mathrm{~N} \mathrm{ha}^{-1}$ and topped at 15 leaf stage (2414

\section{REFERENCES}

Anuradha, M., Nageswararao, K. Chandra shekarao C. and Krishnamurthy. V. (2010) Effect of nitrogen levels on growth, yield and quality of flue-cured tobacco. Tobacco Research 36: 55-8.

Basha, S.J., Prabhakar, K. Manjunath, J., Pullibai, P. and Chandrasekhara Rao, C. (2018) Production potential of bidi tobacco (Nicotiana tabacum L.) varieties to varied levels of nitrogen and topping under rainfed conditions in vertisols of Andhra Pradesh. Tobacco Research 44 (2): 54-57.

Bglar, P.S. and Behghan, Z. (2014) Effect of topping and suckericide on leaf quality of tobacco (Nicotiana tabacum L.).International Journal of Advanced Biological and Biomedical Research 2(3):723-731.

Damodar Reddy D. (2015) Annual report, All India net work project 2014-15 CTRI Rajahmundry pp 173-174.

Guo H, Kan Y, and Liu W, 2011.Differential expression of miRNAs in response to $\mathrm{kg} / \mathrm{ha}$ ) and $110 \mathrm{~kg} \mathrm{~N} \mathrm{ha}^{-1}$ and topped at 15 leaf stage (2329 kg ha-1) (Table 2). The lower cured leaf yield was recorded with variety Nandyal pogaku-1 under different $\mathrm{N}$ levels and topping leaf stages. This may be attributed to greater response of $N$ to variety $A B D 132$ at different topping leaf stages as compared to Nandyal pogaku-1 variety.It may be concluded from the results that, ABD 132 was responding to higher levels of nitrogen and topping and performing better than Nandyal Pogaku 1 in terms of cured leaf yield, leaf quality and net returns. ABD 132 could be accepted for suitability for commercial cultivation in bidi tobacco growing areas of Andhra Pradesh with $140 \mathrm{~kg} \mathrm{~N} \mathrm{ha}^{-1}$ and topping at 15 leaf stage.

\section{ACKNOWLEDGEMENT}

The authors are grateful to All India Network Project on Tobacco (AINPT), ICARCTRI, Rajahmundry and Regional Agricultural Research Station, Nandyal, ANGRAU, Andhra Pradesh for providing the facilities for smooth conduct of the experiment.

topping in flue-curedtobacco (Nicotianatabacum) roots. Plos one. 6 (12): 1-15.

Gupta, A.K., Rathour, D.K., Karande, U.N. and Chavda, J.C. (2014) Effect of chemical desuckering on growth, yield and quality of bidi tobacco (Nicotiana tabacum L.) varieties. Trends in Bioscience 7(24): 4328-4331.

Hanumantha Rao. A., Gopalakrishna C.V.S.S.V. and Satyanarayanamurthy, B.V.V. (1980) Determination of chlorides in tobacco by auto-analyser. Tobacco Research 7: 92-5.

Harvey, W.R., Stahr, H.M. and Smith, W.C. (1969) Automated determination of reducing sugars and alkaloids in the same extract of tobacco. Tobacco Science 13: 13-5.

Kasturi Krishna, S., Krishna Reddy S.V. and Krishnamurthy. V. (2004) Effect of spacing, levels of nitrogen and topping on yield and quality of irrigated Natu tobacco (Nicotiana tabacum) grown in Alfisols of Andhra Pradesh. Indian Journal 
of Agronomy 49 (2): 124-7.

Krishna Reddy, S.V., Kasturi Krishna, S., Harishu Kumar, P., Reddy P.R.S. and Adinarayana, G. (2012) Effect of foliar spray of $\mathrm{zn}, \mathrm{mg}$ and topping levels on yield and quality of FCV tobacco cV. Kanchan in northern light soils (alfisols) of Andhra Pradesh. Tobacco Research 38 (2): 78-83, 2012

Kumaresan,K.,

Swamy,

A.V.S.R., Chandrasekara Rao C. and Murthy, T.G.K. (2014) Effect of spacing and nitrogen levels on the first grade leaf yield and quality of chewing tobacco. Tobacco Research 40 (1): 55-58.

Marchetti, R., Castelli, F. and Contillo.R. (2006) Nitrogen requirements for flue-cured tobacco. Agronomy Journal 98: 666-674. Doi: 10.2134/agronj 2005.0105

Marowa, P. Mtait, T. and Rukni, D. (2015) Effect of nitrogen, topping and leaf priming on yield and quality of flue cured tobacco (Nicotiana tabacum L.). International Journal of Innovative Research \& Development, 4 (12)
Panse, V.G. and Sukhatme, P.V. (1985) Statistical Methods for Agricultural workers. ICAR, New Delhi .

Patel, J.A., Patel, A.D., Patel, J.R., Desai D.H. and Hirpara, B.V. (2011) Yield and quality of bidi tobacco variety GT9 as influenced by manures and nitrogen levels under two different soil conditions. Tobacco Research 37 (2): 69-73.

Reed T.D, Johnson CS, Semtner PJ, Wilkinson CA (2012). Flue-cured tobacco production Guide in cooperation with the Virginia Bright Flue-Cured Tobacco Board. Pp: 140.

Sannibabu, M., Deo Singh K. and Athinarayanan, R. (2014) Tip leaf management practices for maximizing ripe leaf production of NLS grown FCV tobacco. Tobacco Research 40 (1): 28-34.

Smith, W. (2009) Managing nutrients. pp. 58-81. In: Flue-cured tobacco guide. North Carolina State University, Raleigh, NC. 